\title{
Point A to Point B
}

\section{Robbie Marshall}

TRAVEL WAS ONCE a privilege, a social event or something to look forward to. A train trip interstate was an adventure that would enthral all your senses, as you were taken into the unknown by a big, shiny, red steam engine. Kids and adults alike would be excited to take their seat and look out the windows at the countryside passing by, places they had never experienced. Plane travel, a long while ago, was rare and only experienced by businessmen and the wealthy.

Not today.

Gone are the rumbling excited voices discussing what they can see outside their wide, unobstructed windows. Now these voices have been replaced by the drone of iPods being played too loud, phones beeping incessantly and the mashing of phone keypads as people frantically text during the journey.

The sounds have gone, and so has the respect. Asking someone where they are going and how they are was once a polite and enjoyable way to pass the time and a way to interact with the travellers near you. Nowadays any interaction between individuals is uncommon. Starting a conversation is difficult when most travellers are too consumed with checking their phones or putting their iPod on shuffle.

But the biggest loss has been the feel of adventure. People look so miserable today on trains, trams and buses. They are completely uninterested and unaware that they are on a journey moving them from one place to another, from point A to point B. The looks on their gloomy faces show distress, depression and general disenchantment.

I was a young boy when I went on my first train trip. My dad and 
grandad took me from our house in Hurstville to Bondi Beach. On our journey we saw the city, Circular Quay, the Harbour Bridge, Kings Cross and then beautiful Bondi as the train slowly creaked along. My eyes were fixated on all the buildings and how they seemed to gain in height the closer we got to the city. I didn't pay much attention to the family with me as I enjoyed the sights, sounds and smells of the old Tangara train.

Now fully grown and matured, like the cityscape, I can see the difference in things. I have only had one great travel memory in the last few years. I was on a plane trip from Sydney to Perth. I took my place in my seat and settled in, excited about the trip. This older lady carefully shuffled in to the window seat next to me.

She buckled up and became transfixed with the view outside the plane. The tarmac was busy with airport vehicles whizzing around doing their tasks as other planes dwarfed them taxiing onto the runways.

Before takeoff she turned to me and smiled, and after a short conversation she told me her name was Grace and this was the first flight she had ever been on. She was probably eighty or so years of age and I found this very interesting so I asked more questions about her. I found out that she was flying to Perth to see her grandson for the first time.

I couldn't gauge what was running through her mind. Was she nervous? Was she excited? Was it all too much for her?

As the plane started to lurch forward towards the runway, Grace's eyes were wide with fear. She gripped the seat tightly with her hands expecting the plane to shoot down the runway at any second. I told her that the takeoff will be quick and painless. She smiled, but I couldn't tell if she believed me or not.

The plane started to shudder as it sped down the runway, the wheels leaving the ground as it rose into the air.

It took a few minutes before the plane levelled out and steadied itself, and Grace and I started talking again. We talked about current events, where we were from, things we enjoyed, but her eyes were pulled back to the window as she could see the roads and buildings slowly start to shrink below us.

Five minutes of silence passed and she looked back at me and said, 'Tommy would have loved this.' A feeling of understanding, empathy and sadness overwhelmed me. Her husband must have passed away and never had the chance to fly. A few tears started running down her cheeks as she 
searched for a handkerchief in her handbag.

For the rest of the flight I was speechless and observed Grace as she stared out the window towards the horizon.

The seatbelt sign lit up for the final time and everyone started getting ready for the landing. Again, Grace gripped the chair arms with all her strength as the plane dropped from 40,000 feet to a few feet off the ground.

The plane landed on that sunny afternoon at Perth Airport, and I could tell Grace was relieved. I waited with her at the airport gate until her daughter arrived to pick her up. Grace's face lit up at the sight of her daughter and her newly born grandson as they walked up the corridor from the bag holding area.

Grace softly picked up the child and then we said our goodbyes. The three of them disappeared into the crowd outside the baggage bay and I never saw Grace again.

That one day of travel resonates in me and I will never forget it. It brought back so many great memories and feelings about how travel should be: an adventure shared by all the individuals going from point $\mathrm{A}$ to point B. Whether you are alone, with family, old, young, for business or pleasure or just the thrill of getting away, it doesn't matter.

Tonight, as I sit on the 57 tram, listening to iPods being blasted and text messages being sent and recieved, I don't feel the same. 